\title{
Dolphin morbillivirus infection in different parts of the Mediterranean Sea
}

\author{
Brief Report \\ M.-F. Van Bressem 1 , I. K. G. Visser ${ }^{2}$, R. L. De Swart ${ }^{2}$, C. Örvell ${ }^{3}$, L. Stanzaní, \\ E. Androukaki ${ }^{5}$, K. Siakavara ${ }^{6}$, and A. D. M. E. Osterhaus ${ }^{1,7}$ \\ ${ }^{1}$ Division of Virology, Institute of Infectious Diseases and Immmunology, \\ Veterinary Faculty, State University of Utrecht, Utrecht, \\ ${ }^{2}$ Seal Rehabilitation and Research Center, Pieterburen, The Netherlands \\ ${ }^{3}$ Department of Virology, Central Microbiology Laboratory of Stockholm City Council, \\ Stockholm, Sweden \\ ${ }^{4}$ Fondazione Cetacea, Riccione, Italy \\ ${ }^{5}$ Hellenic Society for the Study and Protection of the Monk Seal, Athens \\ ${ }^{6}$ Institute of Marine Biology of Crete, Heraklion, Greece \\ ${ }^{7}$ Laboratory of Immunobiology, National Institute of Public Health and Envrionmental \\ Protection, Bilthoven, The Netherlands
}

Accepted August 28, 1992

Summary. Morbillivirus were isolated from Mediterranean striped dolphins (Stenella coeruleoalba) dying along the coasts of Italy and Greece in 1991. They were antigenically identical to the morbilliviruses isolated from striped dolphins in Spain in 1990.

Within the genus Morbillivirus of the family Paramyxoviridae, five different viruses have been recognised, which infect members of different mammalian orders under natural conditions: measles virus (MV) of humans, canine distemper virus (CDV) of dogs and other carnivores, rinderpest virus (RPV) and peste des petits ruminants virus (PPRV) of artiodactyls [4, 7]. The fifth member of the genus, phocid distemper virus-1 (PDV-1) [21], caused a devastating epizootic among the harbour seals (Phoca vitulina) of North Western Europe in $1988[18,19], \mathrm{PDV}-1$ proved to be antigenically and genetically closely related to $\operatorname{CDV}[13,15,24]$. Since this die-off, morbillivirus infections have been described in other pinniped species and cetaceans [11].

In ceteceans, morbilliviruses were isolated from harbour porpoises (Phocoena 
phocoena) stranded on the Irish [12] and Dutch coasts [20]. In the summer of 1990, a morbillivirus associated die-off occurred among the striped dolphins (Stenella coeruleoalba) of the western part of the Mediterranean Sea [1, 5, 8, 22]. From June to August 1991, a high mortality was observed among striped dolphins along the southern coast of Italy [6]. From September 1991 to January 1992, a similar die-off was noticed among striped dolphins in the Greek waters. On the basis of epizootiological data, the mortality was suspected to be the result of an extension of the morbillivirus-associated disease outbreak which previously occurred in the western part of the Mediterranean Sea.

We now document the presence of morbillivirus antigen and morbillivirusspecific serum antibodies in samples from several striped dolphins stranded during this recent die-off. We also report the results of the preliminary antigenic characterization of the morbilliviruses isolated from the lungs of three of these animals.

From May to December 1991 organ material was collected from 23 striped dolphins, two common dolphins (Delphinus delphis), one bottlenose dolphin (Tursiops truncatus) and one Cuvier's beaked whale (Ziphius cavirostris) stranded on the coasts of southern Italy and Greece as indicated in Table 1.

Morbillivirus antigen was detected by a previously described antigen capture ELISA [22] in lung suspensions of four out of the eleven striped dolphins stranded in Italy, of four out of the eight striped dolphins beached in Greece, and not in organ materials of the bottlenose dolphin and the Cuvier's beaked whale. Morbilliviruses were isolated from the lungs of one of the Greek (D 6) and two of the Italian (D2, D 4) animals positive in the antigen detection assay.

Virus isolation was performed in peripheral blood mononuclear cell (PBMC) cultures of a bottlenose dolphin (TT. PBMC). TT. PBMC were inoculated with $10 \%$ suspension prepared from the lungs of four striped dolphins stranded in Italy and two dolphins beached in Greece during the die-off of 1991 (Table 1). They were co-cultivated with Vero cells after 7 days. TT. PBMC and Vero cell monolayers were checked at regular intervals for the development of cytopathic changes. Syncytia were detected in the TT. PBMC cultures inoculated with the lung suspensions of these dolphins within seven days. In the Vero cells cocultivated with these cultures, a cytopathic effect was subsequently observed within the following ten days. Morbillivirus antigen was detected in cell-free supernatants of all of these cultures, using the antigen capture ELISA. Nucleocapsids typical for the members of the family Paramyxoviridae were observed in infected cell-lysates by negative contrast electron microscopy (not shown).

In order to assess whether an epizootiological link had existed between the outbreaks in the eastern and western parts of the Mediterranean Sea, the reactivities of CDV and PDV-1-specific MoAbs with the morbillivirus isolates were tested in an indirect ELISA [16, 17]. For preparation of ELISA antigens the isolates from Italy (DMV/Lucca/0691, DMV/Trapani/0891) and Greece (DMV/ Zakinthos/0991) were passaged at least four times in Vero cell monolayer cul- 
Morbillivirus infection in Mediterranean striped dolphins

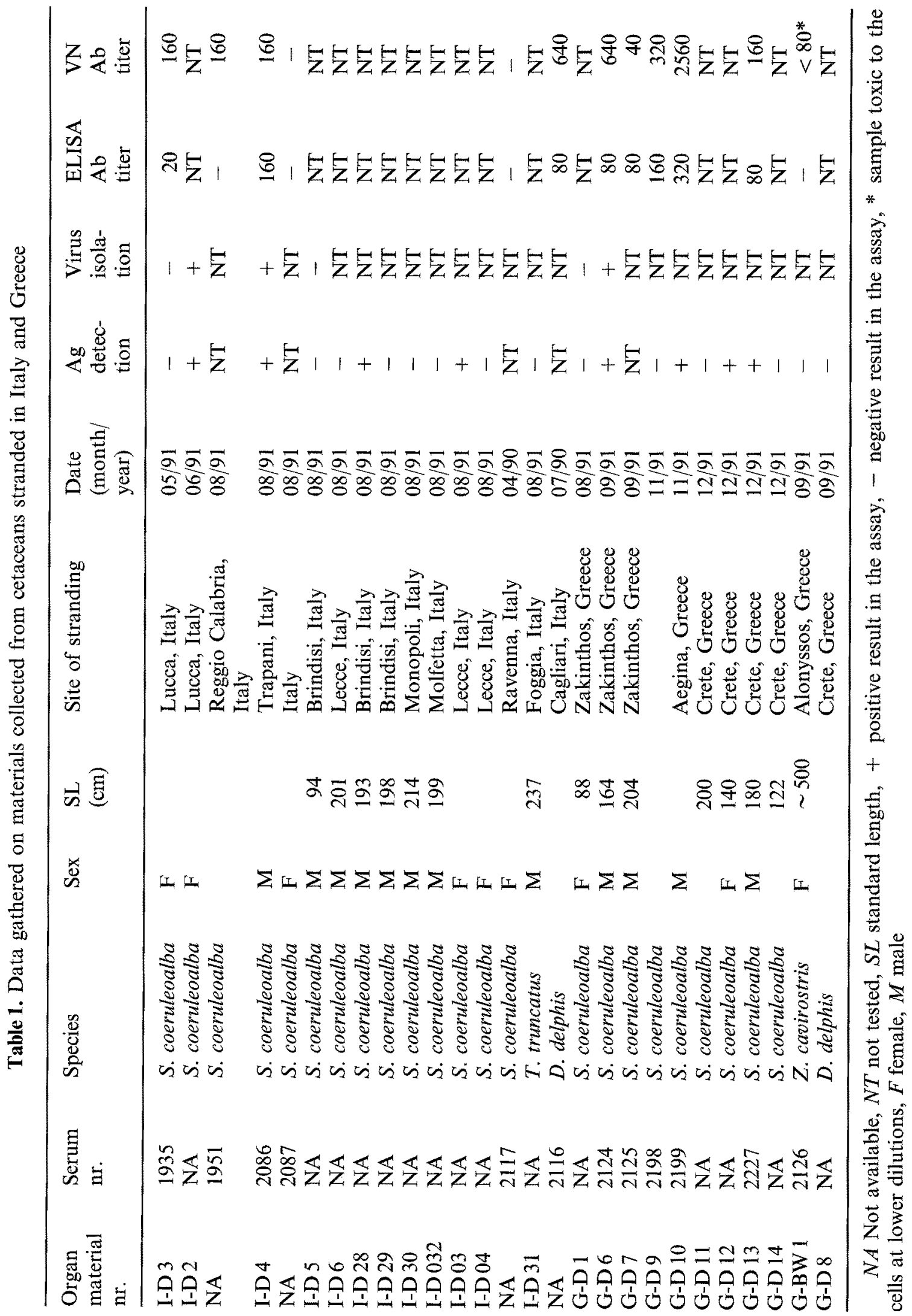


tures. No differences were observed between the reactivity patterns of these viruses with the panel of MoAbs used. The reactivity patterns of the Italian and Greek isolates were also identical to the previously described patterns of the Spanish isolates DMV-16A and DMV-MUC [20] (Table 2).

Morbillivirus neutralizing antibodies present in the serum samples were detected in a micro-neutralization assay [23] using about $100 \mathrm{TCID}_{50}$ of DMV $16 \mathrm{~A}$ and serial two fold dilutions of the serum samples (starting at 1:40). Neutralization titers were expressed as the reciprocals of the dilution still giving complete reduction of cytopathic changes. Morbillivirus neutralizing serum antibodies were detected in three out of four striped dolphins which died in Italy during the 1991 outbreak, in five out of five striped dolphins stranded in Greece and in a common dolphin beached in Italy in July 1990. Virus neutralization titers ranged from 40 to 2560 (Table 1). With the exception of one serum sample (1951), all samples positive in the VN test were also positive in an ELISA detecting morbillivirus specific antibodies [23] on a coat of DMV $16 \mathrm{~A}$ antigen. Morbillivirus-specific antibodies were not detected on the serum from a Cuvier's beaked whale and a striped dolphin stranded in Italy in April 1990 (Table 1).

Table 2. Reaction of monoclonal antibodies raised against CDV with the Spanish (DMV $16 \mathrm{~A}$ and DMV MUC) and the Italian (DMV/Lucca/0691, DMV/Trapani/0891) and Greek (DMV/Zakinthos/0991) isolates of DMV

\begin{tabular}{llllll}
\hline $\begin{array}{l}\text { Designation } \\
\text { of clone }\end{array}$ & Specificity & CDV & $\begin{array}{l}\text { DMV Spain } \\
(\mathrm{n}=2)\end{array}$ & $\begin{array}{l}\text { DMV Italy } \\
(\mathrm{n}=2)\end{array}$ & $\begin{array}{l}\text { DMV Greece } \\
(\mathrm{n}=1)\end{array}$ \\
\hline 3.662 & NP1 & + & - & - & - \\
3.958 & NP3 & + & + & + & NT \\
3.991 & NP 4 & + & - & - & - \\
4.100 & NP 5 & + & - & - & - \\
3.568 & P2 & + & + & + & NT \\
3.695 & P3 & + & - & - & - \\
4.051 & P5 & + & - & - & - \\
4.088 & P6 & + & + & + & + \\
1.347 & H1 & + & - & - & - \\
2.267 & H2 & + & - & - & - \\
3.734 & H3 & + & - & - & - \\
3.775 & H4 & + & - & - & - \\
4.074 & H5 & + & - & - & - \\
4.275 & H6 & + & - & - & - \\
4.941 & H7 & + & - & - & - \\
3.633 & F1 & + & + & + & + \\
3.697 & F2 & + & - & - & - \\
5.148 & F3 & + & - & - & - \\
\hline
\end{tabular}

+ Reactivity in the assay, - no reactivity in the assay; NT not tested 
The detection of morbillivirus antigen in the lungs of several affected striped dolphins and the subsequent isolation of a morbillivirus from capture ELISA positive lung suspensions indicated the role of a morbillivirus infection during the die-off of 1991. Although the DMV isolates originated from striped dolphins stranded in different regions, they exhibited the same reaction patterns in the indirect ELISA with a set of MoAbs raised against CDV and PDV-1 (Tables 2 and 3). These patterns were also identical to those of the two morbilliviruses isolated during the outbreak among striped dolphins in the western part of the Mediterranean Sea [20]. This indicates the existence of an epizootiological link between this outbreak and a similar morbillivirus-related die-off which occurred in the same species, in the western part of the Mediterranean Sea in 1990.

The detection of morbillivirus-specific antibodies in serum samples from several striped dolphins further confirmed the circulation of a morbillivirus in these populations. The presence of VN serum antibodies in absence of ELISA antibodies in one of the sera, may be explained by the fact that the morbillivirusspecific IgM antibodies produced in the acute stage of the infection, were probably not recognized by protein-A used in the ELISA [14]. Furthermore,

Table 3. Reaction of monoclonal antibodies raised against PDV-1 with the Spanish (DMV $16 \mathrm{~A}$ and DMV MUC) and the Italian (DMV/Lucca/0691, DMV/Trapani/0891) and Greek

(DMV/Zakinthos/0991) isolates of DMV

\begin{tabular}{|c|c|c|c|c|c|}
\hline $\begin{array}{l}\text { Designation } \\
\text { of clone }\end{array}$ & Specificity & PDV-1 & $\begin{array}{l}\text { DMV Spain } \\
(\mathrm{n}=2)\end{array}$ & $\begin{array}{l}\text { DMV Italy } \\
(\mathrm{n}=2)\end{array}$ & $\begin{array}{l}\text { DMV Greece } \\
(\mathrm{n}=1)\end{array}$ \\
\hline $1.064 \mathrm{C} 5$ & NP 1 & + & - & - & - \\
\hline $1.071 \mathrm{E} 2$ & NP 1 & + & - & - & - \\
\hline $1.069 \mathrm{G} 2$ & NP 2 & + & - & - & - \\
\hline $1.062 \mathrm{G} 5$ & H 1 & + & - & - & - \\
\hline $1.063 \mathrm{C} 3$ & H 1 & + & - & - & - \\
\hline $1.063 \mathrm{E} 9$ & H 1 & + & - & - & - \\
\hline $1.069 \mathrm{D} 9$ & H 1 & + & - & - & - \\
\hline $1.071 \mathrm{E} 5$ & H 1 & + & - & - & - \\
\hline $1.067 \mathrm{E} 5$ & $\mathrm{H} 2$ & + & - & - & - \\
\hline $1.068 \mathrm{~F} 2$ & H 3 & + & - & - & - \\
\hline 1.070 B 5 & $\mathrm{H} 4$ & + & - & - & - \\
\hline $1.072 \mathrm{C} 4$ & $\mathrm{H} 4$ & + & - & - & - \\
\hline $1.085 \mathrm{C} 4$ & H 5 & + & - & - & - \\
\hline $1.122 \mathrm{D} 11$ & H 6 & + & - & - & - \\
\hline $1.062 \mathrm{E} 2$ & F 1 & + & - & - & - \\
\hline 1.068 B 2 & F 1 & + & - & - & - \\
\hline $1.067 \mathrm{D} 2$ & F 2 & + & + & + & + \\
\hline $1.073 \mathrm{G} 10$ & F 3 & + & + & + & + \\
\hline $1.092 \mathrm{C} 3$ & F 3 & + & + & + & + \\
\hline
\end{tabular}

+ Reactivity in the assay, - no reactivity in the assay 
the relatively low levels of antibodies demonstrated in the ELISA vs. VN antibodies may have been caused by a limited reactivity of protein A for Ig of cetacean origin. The presence of morbillivirus neutralizing and ELISA-reactive antibodies in a common dolphin indicated that this animal had also suffered from a morbillivirus infection. Unfortunately, from this animal no materials were available for antigen detection or virus isolation. The limited number of samples from other cetacean species makes it difficult to conclude whether they are also susceptible to DMV infection. Our success in isolating DMV in lymphocytes from a bottlenose dolphin suggests that other cetacean species could be infected by DMV. However, although the striped dolphin can be seen swimming together with other cetaceans like the common dolphin [9] and the shortfinned pilot whale (Globicephala macrorhynchus) [10], the die-off was so far only reported to affect the endangered Mediterranean striped dolphin [3]. Besides a possible higher susceptibility to DMV infection and DMV associated disease development, the tendency of the striped dolphin to form groups of dozens of animals [2] may have favoured the spread of the infection in this species. The high mortality rate during the die-off indicates that DMV had entered a non-immune population [4].

Speculations that the recent morbillivirus related mortality in striped dolphins was the result of transmission of PDV-1 from seals to dolphins can now be contradicted on the basis of the antigenic differences between these two viruses. Also the natural tendency of the morbillivirus to be confined to one mammalian order, and the biological differences shown between PDV-1 and DMV [20] indicate that there has been no etiological link between the PDV1 and DMV related outbreaks.

The identification of at least two new members of the genus Morbillivirus causing devastating outbreaks among aquatic mammals raises questions about the origin of these viruses, the reason for their sudden appearance and their antigenic or genetic relationships with the other members of the genus. These questions are subject of our present investigations in this field.

\section{Acknowledgements}

We kindly acknowledge J. S. Teppema for the electron microscopy, R. Basso, A. Bortolotto, L. Casini, A. Di Natale, G. Gnone, M. G. Hartmann, the Italian Centre for Cetacean Studies, the Italian Merchant Ministry, V. Kouroutos, L. Lino, C. Meotti, E. Tounta, L. Vedder and V. Zavras, for their help in collecting the samples, Dr. P. J. H. Van Bree for the identification of the Cuvier's beaked whale, A. Vecchione for her appreciated assistance during the processing of the samples, and C. Kruyssen for help in preparing the manuscript.

\section{References}

1. Aguilar A (1990) Dolphin die-off in the Western Mediterranean. ECS Newslett 9: 4

2. Anonymous (1990) Technical report on the situation of small cetaceans in the mediterranean and the impact of fishing gear and fishery practices on these animals. Greenpeace International, November 1990

3. Anonymous (1991) Report on the workshop on the mortality in passive fishing nets 
and traps, La Jolla, California, USA, 22-25 October 1990. International Whaling Commission Report

4. Black F (1991) Epidemiology of paramyxoviruses. In: Kingsburry D (ed) The paramyxoviruses. Plenum, New York, pp 509-536

5. Bompart JM, Dhermain F, Poitevin F, Cheylan M (1991) Les dauphins méditerranées victimes d'un virus mortel. La Recherche 231: 506-508

6. Bortolotto A, Casini L, Stanzani LA (1992) Dolphin mortality along the Southern Italian coast. Aquatic Mammals (in press)

7. De Vries P, Osterhaus ADME (1992) Vaccines against morbillivirus infections. In: Höglund S, Pandey R (eds) Progress in vaccinology, vol 4: veterinary vaccines. Springer, Berlin Heidelberg New York Tokyo (in press)

8. Domingo M, Ferrer L, Pumarola M, Marco A, Plana J, Kennedy S, McAliskey M, Rima BK (1990) Morbillivirus in dolphins. Nature 348: 21

9. Ellis R (1989) Dolphins and porpoises. AA Knopf, New York

10. Heimlich-Boran JR, Heimlich-Boran SL (1990) Occurrence and group structure of the short-finned pilot whale Globicephala macrorhynchus off the Western coast of Teneriffe, Canary Island. In: Evans PGH, Aguilar A, Mink C (eds) Proceedings of the fourth annual conference of the European Cetacean Society, Palma de Majorca 1990. European Cetacean Society, Cambridge, England, pp 102-103

11. Kennedy S (1991) A review of the 1991 European seal morbillivirus epizootic. Vet Rec 8: $563-567$

12. Kennedy S, Smyth JA, Cush PF, McCullogh SJ, Allan GM, McQuaid S (1988) Viral distemper now found in porpoises. Nature 336: 21

13. Kovamees J, Blixenkrone-Möller M, Sharma B, Örvell C, Norrby E (1991) The nucleotide sequence and deduced amino acid composition of the haemaglutinin and fusion proteins of the morbillivirus phocid distemper virus. J Gen Virol 72: 2959-2966

14. Lindmark R, Thoren-Tholling K, Sjoquist J (1983) Binding of immunoglobulins to Protein A and immunoglobulin levels in mammalian sera. J Immunol Methods 62: 113

15. Mahy BWJ, Barrett T, Evans SA, Anderson EC, Bostock CJ (1988) Characterization of a seal morbillivirus. Nature 336: 115

16. Örvell C, Blixenkrone-Möller M, Svansson V, Have P (1990) Immunological relationships between phocid and canine distemper virus studied with monoclonal antibodies. J Gen Virol 71: 2085-2092

17. Örvell C, Shesheberadaran H, Norrby E (1985) Preparation and characterization of monoclonal antibodies directed against four structural components of canine distemper virus. J Gen Virol 66: 443-456

18. Osterhaus ADME, Groen J, Spijkers HEM, Broeders HWJ, UtydeHaag FGCM, De Vries P, Teppema IS, Visser IKG, Van de Bildt MWG, Vedder EJ (1990) Mass mortality in seals caused by a newly discovered morbillivirus. J Vet Microbiol 23: 343-350

19. Osterhaus ADME, Vedder EJ (1988) Identification of virus causing recent seal deaths. Nature 335: 20

20. Osterhaus ADME, Visser IKG, De Swart RL, Van Bressem MF, Van de Bildt MWG, Örvell C, Barrett T, Raga JA (1992) Morbillivirus threat to Mediterranean monk seals? Vet Rec 130: 141-142

21. Pringle CR (1991) Paramyxoviridae. In: Francki RIB, Fauquet CM, Knudson DL, Brown F (eds) Classification and nomenclature of viruses. Fifth report of the international committee on taxonomy of viruses. Springer, Wien New York (Arch Virol [Suppl] 2: 242-246)

22. Van Bressem MF, Visser IKG, Van de Bildt MWG, Teppema JS, Raga JA, Osterhaus ADME (1991) Morbillivirus infection in Mediterranean striped dolphins (Stenella coeruleoalba). Vet Rec 129: 471-472 
23. Visser IKG, Kumarev VP, Örvell C, De Vries P, Broeders HWJ, Van de Bildt MWG, Groen J, Teppema JS, Burger MC, UytdeHaag FGCM, Osterhaus ADME (1990) Comparison of two morbilliviruses isolated from seals during outbreaks of distemper in North West Europe and Siberia. Arch Virol 111: 149-164

24. Visser IKG, Van de Bildt MWG, Brugge HN, Reijnders PJH, Vedder EJ, Kuiper J, De Vries P, Groen J, Walvoort HC, UytdeHaag FGCM, Osterhaus ADME (1989) Vaccination of harbour seals (Phoca vitulina) against phocid distemper with two different inactivated canine distemper virus (CDV) vaccines. Vaccine 7: 521-526

Authors' address: A. D. M. E. Osterhaus, Division of Virology, Institute of Infectious Diseases and Immunology, Veterinary Faculty, State University of Utrecht, Yalelaan 1, NL-3508 TD Utrecht, The Netherlands.

Received May 15, 1992 